\title{
Flavonoid glucuronides isolated from spinach inhibit IgE- mediated degranulation in basophilic leukemia RBL-2H3 cells and passive cutaneous anaphylaxis reaction in mice
}

\author{
Yuta Morishita $^{1}$, Emi Saito ${ }^{2}$, Eri Takemura ${ }^{2}$, Ryoma Fujikawa ${ }^{2}$, Ryohei Yamamoto ${ }^{1}$, Masanori Kuroyanagi ${ }^{2}$, Osamu Shirota ${ }^{3}$ and Norio \\ Muto $^{2 *}$ \\ ${ }^{1}$ Program in Life System Science, Graduate School of Comprehensive Scientific Research, Prefectural University of Hiroshima, 562 Nanatsuka, Shobara 727-0023, \\ Japan \\ ${ }^{2}$ Faculty of Life and Environmental Sciences, Prefectural University of Hiroshima, 562 Nanatsuka, Shobara 727-0023, Japan \\ ${ }^{3}$ Kagawa School of Pharmaceutical Sciences, Tokushima Bunri University, 1314-1 Shido, Sanuki 769-2193, Japan
}

\begin{abstract}
We isolated three active constituents from an aqueous extract of spinach leaves by evaluating the inhibitory activity of IgE-mediated degranulation in rat basophilic leukemia RBL-2H3 cells, and determined their chemical structures. These compounds, referred to as SO-1, SO-2 and SO-3, were assessed to be flavonol glucuronides with the same fundamental structure. Among them, SO-1 exhibited the most potent granulation-inhibitory activity at the concentrations of $0.5 \sim 10 \mu \mathrm{g} / \mathrm{ml}$. This inhibitory effect was completely exhibited by its aglycon, which was prepared by the enzymatic treatment of $\beta$-glucuronidase and the chromatographic isolation. These compounds hardly showed cytotoxicity at the same concentration range in RBL-2H3 cell culture. To reveal its inhibitory mechanism, we examined the effects of SO-1 on the signal transduction of antigen-stimulated degranulation in the cells. Both SO-1 and its aglycon reduced the elevation of intracellular $\mathrm{Ca}^{2+}$ concentration in a dose-dependent manner and also effectively inhibited the activation of tyrosine kinases such as Syk and Lyn, which underlay in the upstream of intracellular signal transduction followed by antigen stimulation. Furthermore, both SO-1 and its aglycon remarkably suppressed the passive cutaneous anaphylaxis (PCA) reaction induced in ICR mouse ear, as compared with the authentic anti-allergic drugs. In this PCA reaction, the aglycon exerted more potent inhibitory activity than SO-1, indicating that SO-1 also functions in vivo through the hydrolysis to the aglycon in the gastrointestinal tract. Together with these results, we conclude that spinach contains the promising anti-allergic flavonoid glucuronide, suggesting that this compound and its original vegetable may be beneficial to prevent or ameliorate allergic constitutions of humans.
\end{abstract}

\section{Introduction}

Recently, the number of type 1 allergy patients has been increasing in the world, especially in developed and industrialized countries. This is one of most important healthcare problems to be resolved. Type I allergy exerts symptoms of acute inflammation reactions like asthma and rhinitis. Type 1 allergy reaction is mediated by the specific binding of polyvalent allergens to the corresponding IgE receptors (Fce R1) on the surface of mast cells and basophils $[1,2]$. Then, the antigenbinding to the cells immediately triggers the intracellular signal cascade leading to the final release of chemical mediators, such as histamine, serotonin, arachidonic acid metabolites, proteases, heparin, and so on, from intracellular granules, followed by the occurrence of acute allergic symptoms. Thus, mast cell plays a critical role in the allergic reaction $[3,4]$, indicating that the regulation of such hypersensitivity of the cells is considered to be very important for the prevention and/or amelioration of allergic constitution of humans.

So far, various types of drugs including histamine blockers and degranulation inhibitors have been developed and employed for the medical treatment. However, these chemically synthesized drugs have been reported to exhibit some side effects together with their potent effects. In order to prevent or ameliorate such symptoms of type I allergy, it has been focused on the screening of promising natural resources including fruits, herbs and plants, which possess moderate inhibitory activities of degranulation in cellular systems. However, there are hardly reported that very popular vegetables have such effects in in vitro and/or in vivo assay systems. Spinach, Spinacia oleracea Linn., is a kind of well-known vegetables belonging to the Chenopodiaceae family, which is cultivated world-widely. In the previous papers relating to spinach constituents, it contains a various compound such as nutrients, vitamins, minerals and polyphenolic compounds. To date, it has been reported that spinach has antioxidant effect, anti-mutagenic and anti-inflammatory effects [5-11]. The antioxidant effect of spinach is reported to be mainly due to the flavonoid compounds such as spinacetin glucoside, patuletin glucoside and dioxol flavonoid $[5,7,10]$. On the other hand, some flavonoid compounds isolated from other plants, including quercetin, kaempherol and so on have been shown to inhibit histamine release from rat basophilic leukemia cells $[2,12$ -

Correspondence to: Norio Muto, Faculty of Life and Environmental Sciences, Prefectural University of Hiroshima, 562 Nanatsuka, Shobara 727-0023, Japan, Tel: +81-824-74-1795; Fax: +81-824-74-1795; E-mail: muto@pu-hiroshima.ac.jp

Key words: degranulation, flavonoid glucuronide, PCA reaction, RBL-2H3 cells, spinach

Received: January 10, 2015; Accepted: January 23, 2015; Published: January 27, 2015 
Morishita Y (2015) Flavonoid glucuronides isolated from spinach inhibit IgE-mediated degranulation in basophilic leukemia RBL-2H3 cells and passive cutaneous anaphylaxis reaction in mice

18]. However, it is unknown that spinach has an inhibitory component on both IgE-mediated degranulation from the cells and in vivo allergic reactions.

In this study, we demonstrate the inhibitory effect of an aqueous extract from spinach leaves on IgE-mediated degranulation in RBL$2 \mathrm{H} 3$ cells and the isolation of three active compounds based on the biological evaluation test. All compounds are identified as flavonoid glucuronides with the same fundamental skeleton, which are specific to spinach. By using the most active compound, we examine the underlying mechanism to inhibit the degranulation in cellular response. Furthermore, we clarify the inhibitory effects of both the glucuronide and its aglycon on passive cutaneous anaphylaxis (PCA) reaction in mice.

\section{Materials and methods}

\section{Materials}

RBL-2H3 cells were obtained from JCRB (Saitama, Japan) and maintained under the culture conditions recommended by the cell bank. Eagle's minimum essential medium (MEM), bovine serum albumin (BSA), mouse anti-dinitrophenol (anti-DNP) monoclonal IgE, DNP-conjugated human serum albumin (DNP-HSA), calcium ionophore A23187, oxatomide, gum arabic, Evan's blue dye and $\beta$-glucuronidase (EC 3.2.1.32, Type HP-2 from Helix pomatia) were purchased from Sigma (St. Louis, MO). Fetal bovine serum (FBS) was obtained from HyClone Laboratories (Utah, USA). Anti-phosphoSyk (Tyr525/526) rabbit monoclonal antibody, anti-phospho-Lyn (Tyr507) rabbit polyclonal antibody and horseradish peroxidaseconjugated anti-rabbit IgG (Goat) were purchased from Cell Signaling Technology, MA, USA). WST-1 and 1-methoxy PMS were the products of DOJINDO Laboratories (Kumamoto, Japan).

\section{Extraction and isolation procedures}

Fresh spinach was purchased from the local supplier in Shobara city, Hiroshima, Japan. Spinach leaves $(1.34 \mathrm{~kg})$ were vigorously ground with 2 volumes of hot distilled water in a food processor and mixed for 1 hour at $80^{\circ} \mathrm{C}$ in a mechanical stirrer. Then, spinach mixture was separated into an aqueous extract and residual substances using double-layered gauze. This procedure toward the residual substances was repeated in a similar manner. The spinach extract obtained was first examined for its inhibitory activity of IgE-mediated degranulation in RBL-2H3 cells under the serial dilution of original sample. Total aqueous extract $(6 \mathrm{~L})$ was subjected to a Diaion HP20 column chromatography (Mitsubishi Chemical, Tokyo, Japan) $(45 \times 3$ $\mathrm{cm}$ ) eluted with distilled water and methanol (Kanto Chemical, Tokyo, Japan). The methanol fraction was concentrated in vacuo using a rotary evaporator at $45^{\circ} \mathrm{C}$ and further chromatographed on a Sephadex LH-20 column (Amersham Biosciences) $(30 \times 2 \mathrm{~cm})$ eluted with distilled water and $70 \%$ aqueous acetone. Elution was conducted with 2 columnvolumes of distilled water and separated into 3 fractions (Fr. W-1, W-2 and W-3) with different visible colors, such as black, red and yellow, respectively. Among these three aqueous fractions and acetone fraction, the most effective fraction (Fr. W-3, $1.21 \mathrm{~g}$ ) was concentrated and subjected to a thin layer chromatography (TLC, Silica gel, Merck Ltd., Japan) using $\mathrm{CHCl}_{3}-\mathrm{MeOH}-\mathrm{H}_{2} \mathrm{O}$ (6:4:1). The yellow fraction was separated on a preparative thin layer chromatography (pTLC, Silica gel, Merck Ltd. Japan) using $\mathrm{CHCl}_{3}-\mathrm{MeOH}-\mathrm{H}_{2} \mathrm{O}$ (6:4:1) and yielded six fractions. Among them, the most active fraction (Fr.4, $408 \mathrm{mg}$ ) was separated by a high performance liquid chromatography (HPLC) using a Mightysil RP-18 GP column $(250 \times 10 \mathrm{~mm}, 5 \mu \mathrm{m}$, Kanto Chemical,
Tokyo, Japan) eluted with $26 \% \mathrm{AcCN}-0.02 \%$ trifluoroacetic acid (TFA) at a flow rate of $2.0 \mathrm{ml} / \mathrm{min}$. Elution was monitored at $260 \mathrm{~nm}$ using UV-VIS detector (SPD-10A VP, Shimadzu, Japan). The active fractions (Fr.4-2, 4-3, 4-4) were finally purified by HPLC eluted with $22 \% \mathrm{AcCN}-0.02 \% \mathrm{TFA}$. The purity of the isolated compounds was confirmed by an analytical HPLC. The final yields of SO-1 from Fr. 4-4, SO-2 from Fr. 4-2 and SO-3 from Fr. 4-3 were 4.2, 3.6 and $3.8 \mathrm{mg}$, respectively.

\section{Assessment of chemical structures}

The chemical structures of three compounds isolated from spinach were assigned by the instrumental analyses of ${ }^{1} \mathrm{H}-\mathrm{NMR}(700 \mathrm{MHz}$, $\left.\mathrm{C}_{5} \mathrm{D}_{5} \mathrm{~N}\right),{ }^{13} \mathrm{C}-\mathrm{NMR}\left(175 \mathrm{MHz}, \mathrm{C}_{5} \mathrm{D}_{5} \mathrm{~N}\right)$ and $2 \mathrm{D}-\mathrm{NMR}$ (HMBC and ROESY), together with the data reported in the previous papers describing the compounds isolated from spinach [5,7,10]. SO- 1 , faint yellow powder, was identified as 5,3',4'-trihydroxy-3-methoxy6,7-methylenedioxyflavone-4'- glucuronide. HR-ESI-MS was $\mathrm{m} / \mathrm{z}$ $521.0941[\mathrm{M}+\mathrm{H}]^{+}\left(\right.$calcd. 521.0931 for $\left.\mathrm{C}_{23} \mathrm{H}_{21} \mathrm{O}_{14}\right)$ [5]. SO-2, faint yellow powder, was identified as axillarin- 4 '- $\beta$-glucuronide. HR-ESI-MS was $\mathrm{m} / \mathrm{z} 523.1088[\mathrm{M}+\mathrm{H}]^{+}$(calcd. 523.1088 for $\left.\mathrm{C}_{23} \mathrm{H}_{23} \mathrm{O}_{14}\right)$ [10]. SO-3, faint yellow powder, was identified as jaceidin- 4 '- $\beta$-glucuronide. HR-ESIMS was m/z 537.1234 [M+H] $]^{+}\left(\right.$calcd. 537.1244 for $\left.\mathrm{C}_{24} \mathrm{H}_{25} \mathrm{O}_{14}\right)$ [7].

\section{Determination of $\beta$-hexosaminidase release from RBL-2H3 cells}

IgE-mediated degranulation assay: RBL-2H3 cells (JCRB) were dispensed into a 96 well plate at a cell density of $5 \times 10^{4}$ cells/well using Eagle's minimum essential medium containing $10 \%$ FBS. To each well, $50 \mathrm{ng} / \mathrm{ml}$ of anti-DNP IgE was added and incubated at $37^{\circ} \mathrm{C}$ for $24 \mathrm{~h}$ under humidified $5 \% \mathrm{CO}_{2}-95 \%$ air for sensitization of the cells. Blank and control wells were added with the same volume of Tyrode HEPES buffer containing 1\% BSA. The cells were washed twice with Tyrode HEPES buffer and then incubated with $80 \mu \mathrm{l}$ of Tyrode HEPES containing various concentrations of samples at $37^{\circ} \mathrm{C}$ for $30 \mathrm{~min}$. Then, $20 \mu \mathrm{l} /$ well of Tyrode HEPES buffer or antigen solution containing DNP-HSA at a final concentration of $50 \mathrm{ng} / \mathrm{ml}$ was added to each well and incubated at $37^{\circ} \mathrm{C}$ for $1 \mathrm{~h}$ to stimulate the cells. After incubation, the supernatant from each well was collected and the cells were lysed with the addition of $100 \mu \mathrm{l}$ of lysis buffer containing $0.1 \%$ Triton $\mathrm{X}-100$. Both supernatant and cell lysate were transferred to a 96-well assay plate at $20 \mu \mathrm{l} /$ well and incubated with $100 \mu \mathrm{l}$ of substrate solution (4-nitrophenyl-N-acetyl- $\beta$-D-glucosaminide in $0.1 \mathrm{M}$ citrate buffer, $\mathrm{pH} 4.5$ ) at $37^{\circ} \mathrm{C}$ for $2.5 \mathrm{~h}$. The reaction was stopped by adding $100 \mu \mathrm{l}$ of $0.2 \mathrm{M}$ borate buffer ( $\mathrm{pH} 9.8$ ) and the absorbance was measured at 415 $\mathrm{nm}$ using a microplate reader (Model 550, BIO-RAD). All test samples were dissolved in dimethylsulfoxide and diluted to an indicated concentration with Tyrode HEPES buffer (final concentration of DMSO is less than $0.1 \%$ ). The percentage of inhibitory effect on the release of $\beta$-hexosaminidase was calculated using the following equation. Inhibition (\%) was calculated as $[1-(\mathrm{S}-\mathrm{B}) /(\mathrm{C}-\mathrm{B})] \times 100$. In this equation, $\mathrm{S}, \mathrm{B}$ and $\mathrm{C}$ express the absorbance of sample-treated well, blank well and control well with stimulant only, respectively.

Calcium ionophore-mediated degranulation assay: RBL-2H3 cells were similarly incubated in 96 well plates at a cell density of $5 \times 10^{4}$ cells/well at $37^{\circ} \mathrm{C}$ for $24 \mathrm{~h}$ under $5 \% \mathrm{CO}_{2}-95 \%$ air. The cells were washed twice with Tyrode HEPES buffer and then incubated with 80 $\mu \mathrm{l}$ of Tyrode HEPES containing various concentrations of samples at $37^{\circ} \mathrm{C}$ for $30 \mathrm{~min}$. Then, $20 \mu \mathrm{l} /$ well of calcium ionophore $\mathrm{A} 23187$ was added and incubated at $37^{\circ} \mathrm{C}$ for $1 \mathrm{~h}$ to stimulate the cells. The following experimental procedures were the same as described above. 


\section{Enzymatic formation of aglycon}

SO-1 was enzymatically treated with $\beta$-glucuronidase (type HP-2 from Helix pomatia. The reaction mixture consisted of $950 \mu \mathrm{l}$ of SO-1 solution $(10 \mathrm{mmol} / \mathrm{l})$ prepared in $0.1 \mathrm{M}$ sodium acetate buffer $(\mathrm{pH} 5.2)$ $0.5 \mathrm{M}$ sodium chloride and $50 \mu \mathrm{l}$ of $\beta$-glucuronidase solution, followed by incubation at $37^{\circ} \mathrm{C}$ for $3 \mathrm{~h}$ in a water bath. After centrifugation for 10 min at $10000 \times g$, the supernatant was recovered and subjected to HPLC to purify the aglycon from SO-1.

\section{Measurement of intracellular $\mathrm{Ca}^{2+}$ concentrations}

Intracellular $\mathrm{Ca}^{2+}$ levels were monitored with Calcium Kit Fura2 (Dojindo Laboratories, Kumamoto, Japan) according to the manufacturer's instructions. RBL-2H3 cells were seeded into a 96-well culture plate at a cell density of $5 \times 10^{4}$ cells/well and treated with antiDNP IgE $(0.5 \mu \mathrm{g} / 10 \mu \mathrm{l} /$ well $)$ at $37^{\circ} \mathrm{C}$ for $24 \mathrm{~h}$ under humidified $5 \%$ $\mathrm{CO}_{2}-95 \%$ air. After washing twice with PBS(-), the cells were incubated with $100 \mu \mathrm{l}$ of Fura-2 AM for $1 \mathrm{~h}$. The treated cells were washed twice with PBS and incubated with sample at the indicated concentrations at $37^{\circ} \mathrm{C}$ for $30 \mathrm{~min}$. Then, the cells were stimulated by the addition of $20 \mu \mathrm{l}$ of DNP-HSA $(0.25 \mu \mathrm{g} / \mathrm{ml})$ and the fluorescence was immediately measured using a fluorometric microplate reader at 340/380 nm for excitation and $510 \mathrm{~nm}$ for emission (Varioskan, Thermo Fisher Scientific, Yokohama, Japan).

\section{Immunoblotting analysis}

RBL-2H3 cells were seeded into a $60 \mathrm{~mm}$ culture dish at $1.0 \times 10^{6}$ cells/dish and treated with anti-DNP IgE for sensitization, followed by treatment with samples and stimulation with DNP-HSA as described above. Fifteen minutes after the stimulation, the cells were removed, washed and finally lysed using lysis buffer. Resultant cell lysates were subjected to sodium dodecyl sulfate-polyacrylamide gel electrophoresis (SDS-PACE) and then transferred onto polyvinylidene fluoride (PVDF) membranes. After blocking for $1 \mathrm{~h}$ in $5 \%$ skim milk, the membrane was incubated with a primary antibody at $4^{\circ} \mathrm{C}$ overnight, followed by incubation with a horseradish peroxidase-conjugated secondary antibody at room temperature for $1 \mathrm{~h}$. Immunoreactive proteins were detected with the enhanced ECL kit and chemiluminescence detector (EZ Capture, ATTO Corporation, Tokyo, Japan).

\section{Cytotoxicity assay in RBL-2H3 cells}

RBL-2H3 cells were dispensed into 96 well plates at a cell density of $5 \times 10^{4}$ cells/well using MEM containing $10 \%$ fetal bovine serum. The mixture was incubated for $3 \mathrm{~h}$ at $37^{\circ} \mathrm{C}$ under humidified $5 \% \mathrm{CO}_{2}-$ 95\% air for adhesion to microplate of the cells. Then, the cells were incubated with test sample $(100 \mu \mathrm{l})$ at $37^{\circ} \mathrm{C}$ for additional $24 \mathrm{~h}$. To each well, $20 \mu \mathrm{l} /$ well of WST-1 solution (5 mM WST-1-20 mM 1-methoxy PMS ) was added and incubated at $37^{\circ} \mathrm{C}$ for $2 \mathrm{~h}$ under humidified $5 \%$ $\mathrm{CO}_{2}-95 \%$ air. The absorbance of each well was measured at $415 \mathrm{~nm}$ using a microplate reader. Based on the data obtained, the percentage of cytotoxicity was calculated as relative cell viability.

\section{PCA reaction in mice}

Five-week-old male ICR mice weighing 30-35 g (CLEA Japan, Inc., Tokyo, Japan) were housed in an air-conditioned room $\left(23 \pm 2^{\circ} \mathrm{C}\right)$ with a $12 \mathrm{~h}$ light and dark cycle. Mice were fed commercial pellets and water ad libitum. This study was approved by the Animal Use Committee of Prefectural University of Hiroshima and the animals were maintained according to the guidelines for the care of laboratory animals of Prefectural University of Hiroshima.
An IgE-induced passive cutaneous anaphylaxis (PCA) reaction was carried out as follows. Each mouse was intradermally injected with 20 $\mu \mathrm{l}$ of anti-DNP-IgE antibody $(5 \mu \mathrm{g} / \mathrm{ml})$ in right-side ear and the same volume of saline in left-side ear. After $24 \mathrm{~h}$, the sample solution of SO-1 or its aglycon was orally administered to mice at the indicated doses. These samples and oxatomide used as a positive control were all suspended into gum arabic solution and given to mice at the dose of $0.1 \mathrm{ml} / 10 \mathrm{~g}$ body weight. Two hour after this treatment, the mice were received an intravenous injection of saline containing DNP-HSA at $0.4 \mathrm{mg} / \mathrm{ml}$ and $1 \%$ Evan's blue (SIGMA-ALDRICH). After $30 \mathrm{~min}$ of this injection, mice were sacrificed by cervical dislocation and their ears were removed. Each ear was immersed in $500 \mu \mathrm{l}$ of $1 \mathrm{~N} \mathrm{KOH}$ solution and dissolved overnight at room temperature. The extravasated Evan's blue dye was extracted with acetone- $0.2 \mathrm{M}$ phosphoric acid solution (13:5), centrifuged for $20 \mathrm{~min}$ at $700 \times g$ and measured for the amount of dye at $620 \mathrm{~nm}$ in a spectrophotometer (V-530, Jasco). From the data obtained, the percentage of inhibitory effect on PCA reaction by test samples was calculated.

\section{Statistical analysis}

To assess the degranulation data, a uniformity of variances of data was identified by Bartlett's analysis and then two-way analysis of variance and Tukey's test were used for statistical significance of differences. To assess the PCA reaction data, differences between two groups were statistically evaluated by two-tailed Student's $t$-test.

\section{Results}

\section{Isolation and chemical structures of active compounds from spinach}

The aqueous extract of spinach leaves showed an apparent inhibition of IgE-mediated degranulation in RBL-2H3 cells by using the sequentially diluted samples (Figure 1). The extract was separated by column chromatography including Diaion HP20 and Sephadex LH-20, preparative thin layer chromatography and repeated HPLC. On the basis of cellular assays of degranulation-inhibitory activity, three yellowish compounds with the similar chromatographic behaviors were finally isolated. The flow chart of isolation is shown in Figure 2. Based on the data of the NMR and MS analyses of SO-1, its chemical structure was assigned as 5,3',4'-trihydroxy-3-methoxy-6,7methylenedioxyflavone-4'-glucuronide (Figure 3), being the same compound as 6-(3,4- dihydroxy-phenyl)-9-hydroxy-7-methoxy-[1,3] dioxolo $[4,5$-g]chromen-8-one-4'- $\beta$ - glucuronide reported by Bergman et al. [5]. This compound has been reported to have antioxidant activity

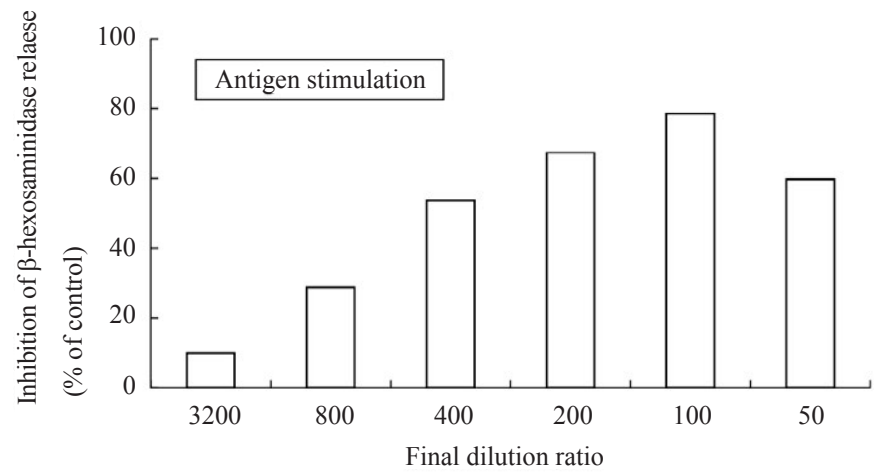

Figure 1. Inhibitory effect of an aqueous spinach extract on antigen-stimulated degranulation in RBL-2H3 cells. 


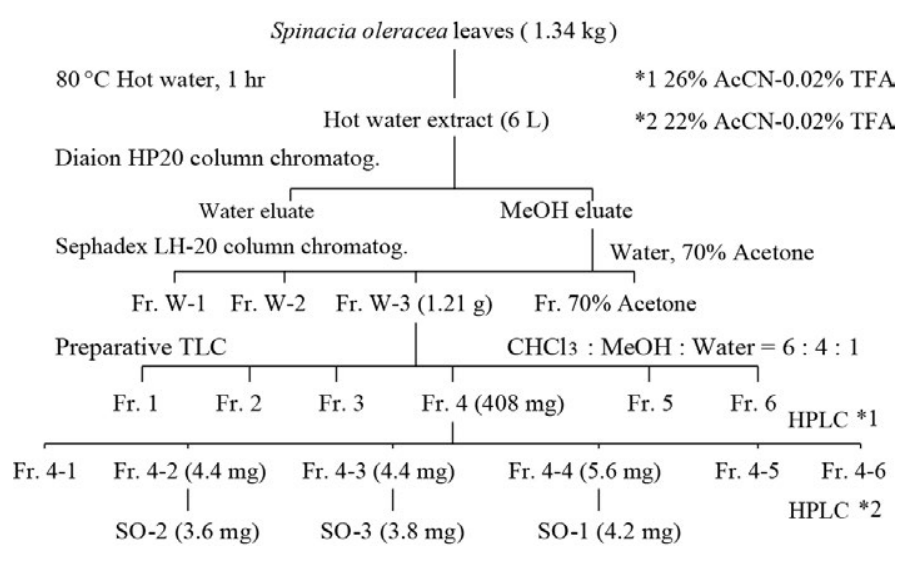

Figure 2. Flow chart of isolation of active compounds from spinach.

SO-1<smiles></smiles>

SO-2<smiles>COc1c(O)cc2oc(-c3ccc(O)c(O)c3)c(OC(=O)OC34OC(=O)C(O)C(O)C3O4)c(=O)c2c1O</smiles>

$\mathrm{SO}-3$<smiles>COc1cc(-c2oc3cc(O)c(OC)c(O)c3c(=O)c2OC(=O)C2OC3OC2C(O)C(O)C3O)ccc1O</smiles>

Figure 3. Chemical structures of SO-1, SO-2 and SO-3 isolated from spinach. in that paper and considered to be a constituent specific to spinach. Similarly, the NMR and MS data of SO-2 and SO- 3 were in agreement with the literature values of axillarin- 4 '- $\beta$-glucuronide and jaceidin4 '- $\beta$-glucuronide $[7,10]$, respectively (Figure 3). Thus, these three compounds were shown to have the very similar characteristics on chemical structures such as the same fundamental skeleton of flavonol and the presence of glucuronic acid at C' 4 in $\beta$-configuration.

\section{Inhibitory effects of spinach glucuronides on the degranulation from RBL-2H3 cells}

Among these three flavonol glucuronides isolated from spinach, the compound, named SO-1, exhibited a remarkably potent inhibitory effect on IgE-mediated degranulation in RBL-2H3 cells, whereas other two, referred to as SO-2 and SO-3, showed weak activities in the same assay system (Figure 4). SO-1 suppressed the IgE-mediated degranulation even at the concentration of $0.5 \mu \mathrm{g} / \mathrm{ml}$ and its $\mathrm{IC}_{50}$ value was estimated to be $0.97 \mu \mathrm{g} / \mathrm{ml}(1.85 \mu \mathrm{M})$. This activity was markedly higher than that of ketotifen fumarate, an authentic antiallergic drug, with its $\mathrm{IC}_{50}$ value of $114 \mu \mathrm{M}$ estimated in the present study (Figure 4). Since these compounds have the similar chemical structures as described above, it is of a nterest to assess the structureactivity relationship among them. We found that the presence of methylenedioxy linkage at $\mathrm{C} 6$ and $\mathrm{C} 7$ in the A ring of the flavonoid was considered to be essential for degranulation-inhibitory activity. However, all the three compounds had no inhibitory effect on calcium ionophore A23187-induced degranulation in RBL-2H3 cells (data not shown).

(A)

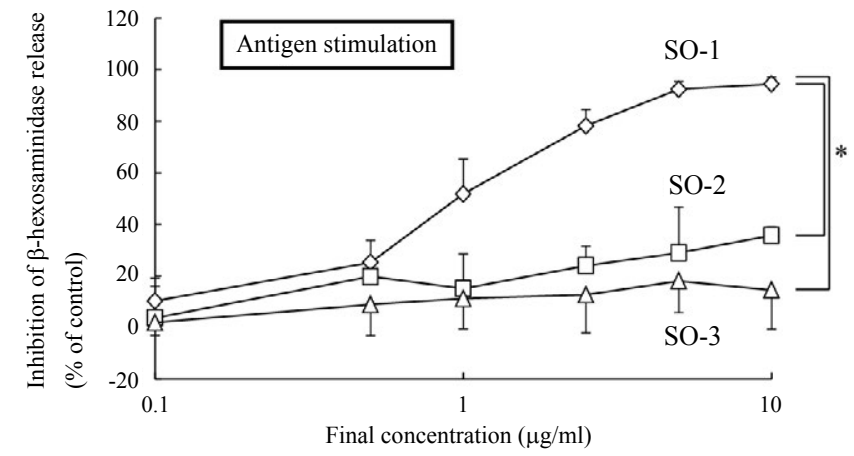

(B)

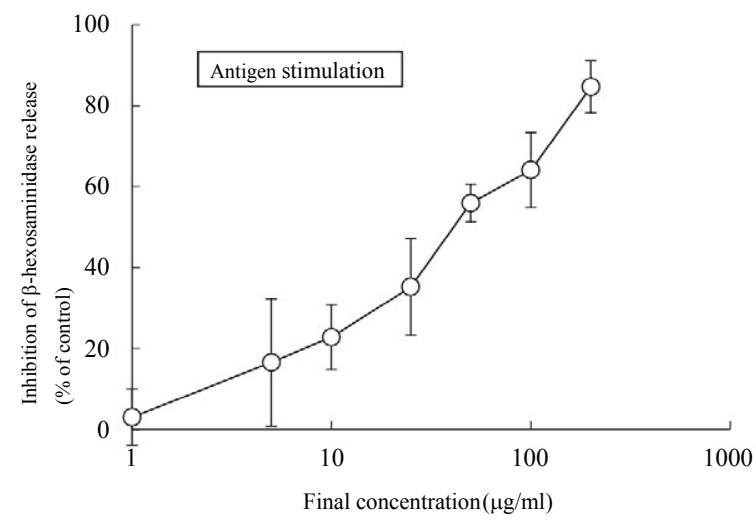

Figure 4. Inhibitory effects of SO-1, SO-2 and SO-3 on antigen-stimulated degranulatio in RBL-2H3 cells. RBL-2H3 cells were treated with each compound from spinach (A) or ketotifen fumarate salt (B) at the indicated concentrations and stimulated with DNP-HSA. The release of $\beta$-hexosaminidase was determined by enzymatic assay. Values are expressed as the means \pm S.D. of three independent assays. 
To further elucidate the functional moiety in SO-1 molecule, we prepared its aglycon from SO-1 by the enzymatic hydrolysis using $\beta$-glucuronidase (Helix pomatia), followed by chromatographic isolation. The purity was confirmed by the elution profile on HPLC and the coincidence of the UV spectrum with that of SO-1 (data not shown). In this treatment, $11.9 \mathrm{mg}$ of aglycon form was recovered from $18.6 \mathrm{mg}$ of SO-1. We compared the inhibitory effects of SO-1 and its aglycon on the $\beta$-hexosaminidase release from RBL-2H3 cells. The aglycon as well as SO-1 strongly suppressed the IgE-mediated degranulation around the same concentration ranges (Figure 5). It showed more potent activity than SO- 1 with the $\mathrm{IC}_{50}$ value of $0.51 \mu \mathrm{g} /$ $\mathrm{ml}(1.47 \mu \mathrm{M})$, indicating that the degranulation-inhibitory activity of SO-1 is caused by the flavonol moiety constituting the glucuronide form. However, the aglycon of SO-1 also had no inhibitory activity on calcium ionophore A23187-stimulated $\beta$-hexosaminidase release in cell assay.

To reveal the mechanism underlying the inhibitory effects of SO-1 and its aglycon on IgE-mediated degranulation in RBL-2H3 cells, we examined both the elevation of intracellular $\mathrm{Ca}^{2+}$ concentration and the phosphorylation of signaling protein kinases induced by the antigen stimulation in the cells. As shown in Figure 6, antigen stimulation immediately increased the release of $\mathrm{Ca}^{2+}$ ions from the endoplasmic reticulum to cytoplasm and such elevation of intracellular $\mathrm{Ca}^{2+}$ levels was effectively suppressed by the treatment of both SO-1 and its aglycon in a dose-dependent fashion. Thus, both compounds were shown to have an ability to suppress the late-stage event of degranulation signaling. In addition, we further examined the earlystage events of degranulation, such as the phosphorylation of Lyn and Syk molecules, which are located in the downstream coupled to antigen-antibody-coupled FceRI complexes. As shown in Figure 7, both SO-1 and its aglycon markedly inhibited the phosphorylation of Syk in a dose dependent manner, whereas they showed weak inhibition of the phospholylation of Lyn at the same concentrations used. These results indicate that the degranulation-inhibitory effects of SO-1 and its aglycon are mainly due to the potent suppression of the activation of Syk following antigen stimulation.

\section{Effects of SO-1 and its aglycon on PCA reaction in mice}

We evaluated the effects of SO-1 and its aglycon on PCA reaction in ICR mice, together with oxatomide as a positive control of antiallergic

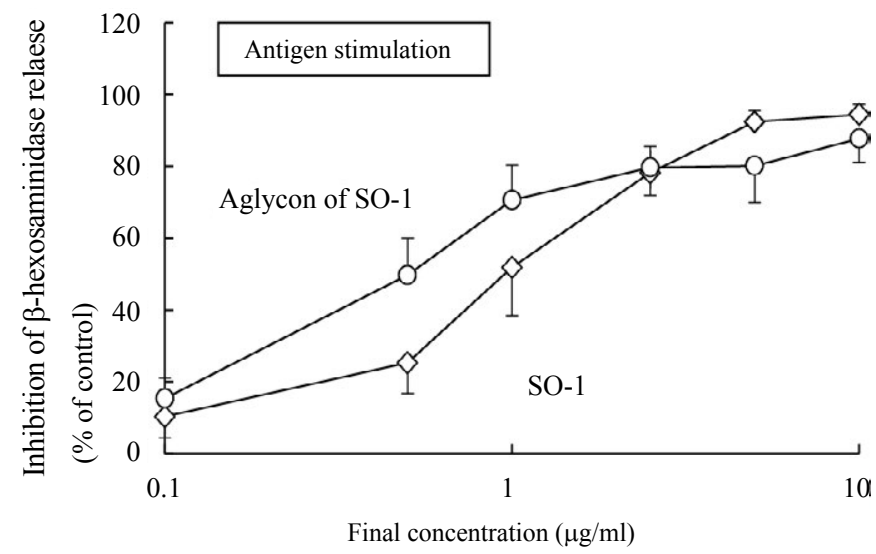

Figure 5. Inhibitory effect of SO-1 and its aglycon by antigen-stimulated degranulation in RBL-2H3 cells. RBL-2H3 cells were treated with each compound at the indicated concentrations and stimulated with DNP-HSA. The release of $\beta$-hexosaminidase was determined by enzymatic assay. Values are expressed as the means \pm S.D. of three independent assays.

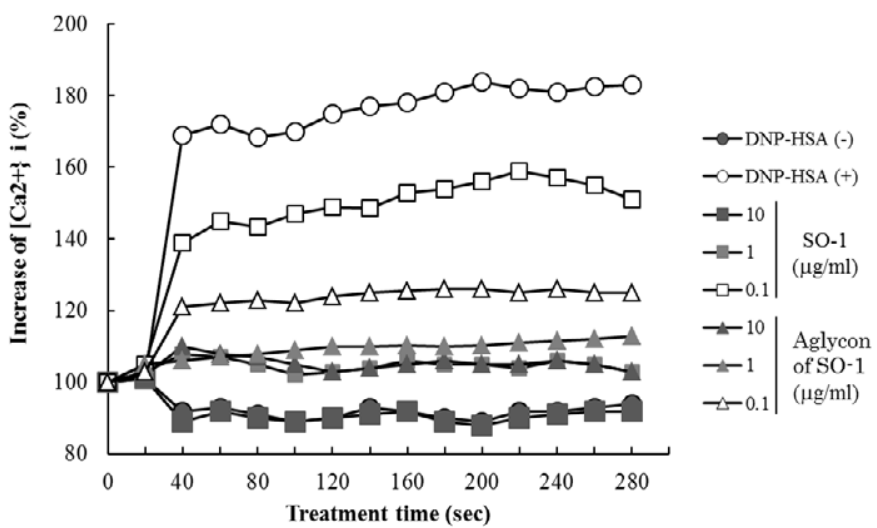

Figure 6. Effects of SO-1 and its aglycon on antigen-stimulated elevation of intracellular $\mathrm{Ca}^{2+}$ levels in RBL-2H3 cells. IgE-sensitized RBL-2H3 cells were treated for $30 \mathrm{~min}$ with or without samples at the indicated concentrations. After the stimulation with antigen at 20 seconds, intracellular $\mathrm{Ca}^{2+}$ levels were measured. A representative result from three independent experiments is shown.

(A)
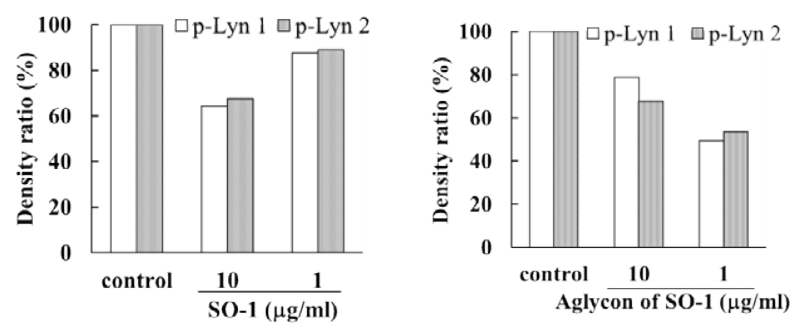

(B)
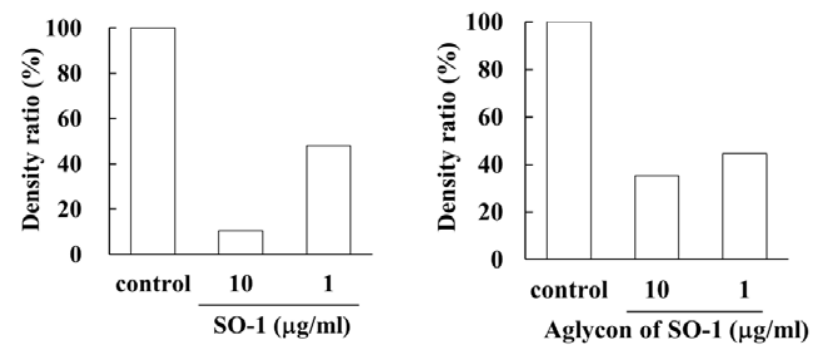

Figure 7. Effects of SO-1 and its aglycon on antigen-stimulated phosphorylation of Lyn and Syk kinases in RBL-2H3 cells. IgE-sensitized RBL-2H3 cells were treated with or without samples at the indicated concentrations. Fifteen minutes after the stimulation with antigen, the cell lysates were subjected to SDS-PAGE and Western blot analysis. Relative density ratios of phosphorylated Lyn 1 and 2 (p-Lyn 1 and p-Lyn 2) (A) and Syk (p-Syk) (B) to controls were calculated. A representative result from two independent experiments is shown in each case.

drug. In this experiment, all compounds suspended in gum arabic solution were administered to mice by gastric intubation. Two hours after antigen stimulation, the amounts of extravasated Evan's blue dye in each ear were extracted and estimated spectrophotometrically. As shown in Figure 8, both SO-1 and its aglycon significantly suppressed the extravasation of dye caused by antigen stimulation. SO- 1 at the dose of $52 \mathrm{mg} / \mathrm{kg}(100 \mu \mathrm{mol} / \mathrm{kg})$ showed more potent suppression in PCA reaction than oxatomide at the dose of $43 \mathrm{mg} / \mathrm{kg}(100 \mu \mathrm{mol} / \mathrm{kg})$. In contrast, the aglycon at the lower dose of $8.5 \mathrm{mg} / \mathrm{kg}(25 \mu \mathrm{mol} / \mathrm{kg})$ completely suppressed the extravasation of dye induced by antigen stimulation, indicating that the aglycon could suppress the PCA reaction more efficiently than $\mathrm{SO}-1$ and oxatomide. 

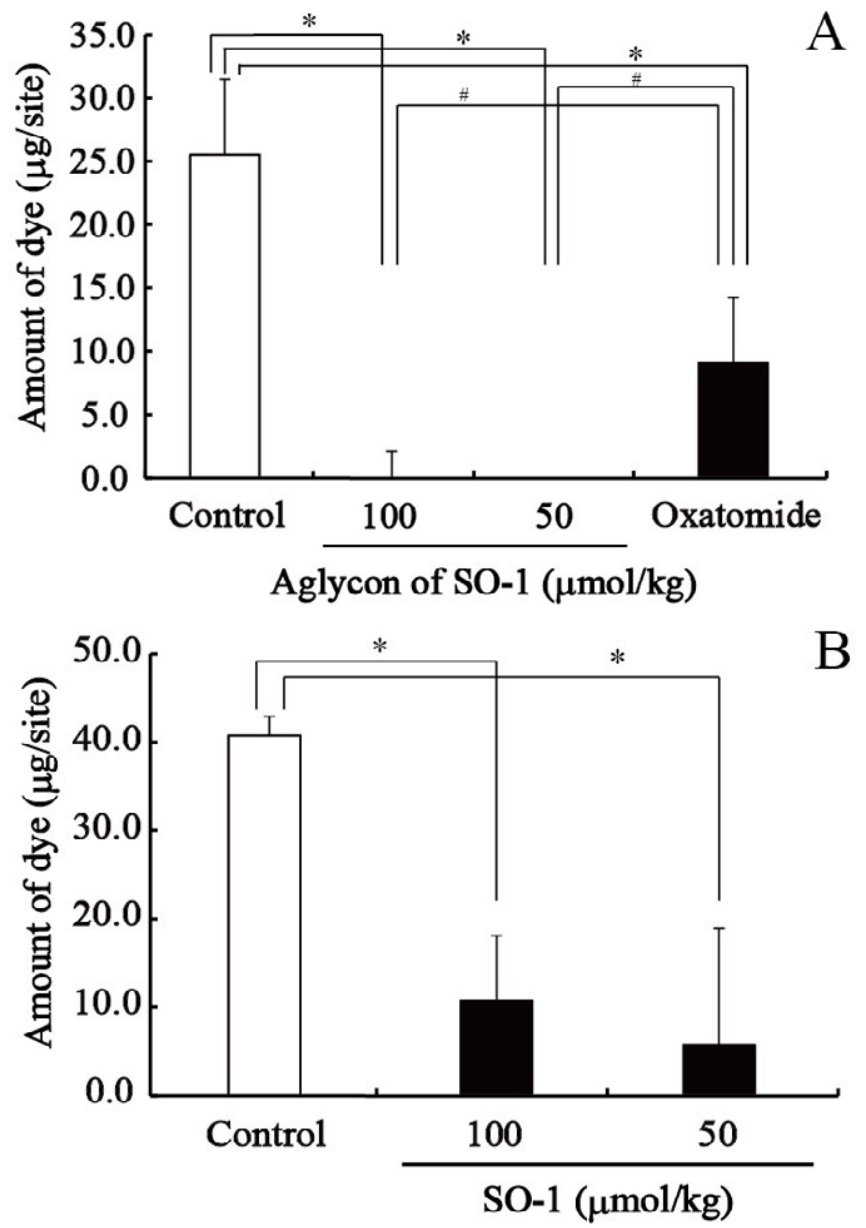

Figure 8. Effect of SO-1 and its aglycon on PCA reaction in mice. A, Mice were administered with the aglycon of SO-1 $(50,100 \mu \mathrm{mol} / \mathrm{kg})$ or oxatomide $(100 \mu \mathrm{mol} / \mathrm{kg})$ $\mathrm{B}$, Mice were administered with SO-1 $(50,100 \mu \mathrm{mol} / \mathrm{kg})$. Each value represents the mean \pm SEM of 4-5 mice. ${ }^{*} p<0.05$ or ${ }^{\sharp} p<0.05$ as compared with the control group or oxatomide group.

\section{Cytotoxicity of spinach glucuronides and its aglycon in RBL- $2 \mathrm{H} 3$ cells}

The cytotoxicities of spinach flavonol glucuronides (SO-1, SO-2 and SO-3) and the aglycon of SO- 1 in RBL- $2 \mathrm{H} 3$ cells were examined for their cytotoxicity at the same concentration ranges used in this study. SO- 1 and its aglycon showed no cytotoxicity at $1 \sim 10 \mu \mathrm{g} / \mathrm{ml}$, whereas SO-2 and SO-3 had a weak cytotoxicity as compared with SO-1.

\section{Discussion}

Recently, it has been focused to search for foods and their constituents to suppress the cellular responses of mast cells and basophils, leading to the prevention or improvement of allergic symptoms. In addition, it is necessary to have a series of evidence to support both in vitro and in vivo effectiveness of these promising materials. Several flavonoids including quercetin, luteolin, kaempferol and myricetin are known to inhibit histamine release from human basophils and rat basophilic leukemia cells $[12,14]$. It has been also reported that some flavonoid glucosides or glucuronides exhibit the inhibitory effect on IgE-mediated degranulation [1,2,14-17]. In this study, we isolated 3 constitutes from an aqueous extract of spinach on the basis of inhibition of IgE-mediated degranulation in RBL-2H3 cells.
These three compounds were all assigned to be flavonol glucuronides with very similar chemical structures and one compound (SO-1) among them exerted remarkably potent activity at an extremely low concentration of $1 \mu \mathrm{g} / \mathrm{ml}$, which is more potent than quercetin and luteolin. The aglycon prepared from SO-1 by enzymatic hydrolysis also showed more potent activity than SO-1, indicating that the active moiety of SO-1 is flavonol, but not glucuronate. From these results, SO-1 and its aglycon are suggested to have the same mechanism to inhibit the IgE-mediated degranulation in RBL-2H3 cells as well as quercetin and luteolin. In fact, SO-1 and its aglycon were demonstrated to inhibit both the elevation of intracellar $\mathrm{Ca}^{2+}$ concentration and the activation of tyrosine kinase (Syk). However, the findings that such activities of SO-1 and its aglycon are strictly due to the presence of a methylenedioxy group at C-6 and C-7 positions and their activities are apparently higher than those of quercetin and luteolin suggest the superiority of spinach as one of the promising vegetables for the improvement of antiallergic constitutions.

Spinach has a notable flavonoid content compared to other flavonoid-rich vegetables such as broccoli and red onion [7]. There are only a few papers describing the biological effects of flavonoids isolated from spinach, such as antioxidative and antimutagenic activities [57]. Very recently, Ishida et al. [19] reported the inhibitory activity of aqueous spinach extract on the degranulation of RBL-2H3 cells. In that paper, they indicated that the active compounds were heat-stable and trypsin-resistant compounds with molecular weights of $0.5 \sim 14 \mathrm{kDa}$, assuming that they may be peptides or water-soluble polysaccharides, but not phytochemicals. Interestingly, their spinach extract inhibited the elevation of intracellular $\mathrm{Ca}^{2+}$ levels and the phosphorylation of Syk kinase caused by antigen stimulation. Thus, although the suppression of IgE-mediated degranulation of RBL-2H3 cells by the aqueous spinach extract was similarly observed in different laboratories, we could identify one active constituent as flavonol glucuronide in this study. This compound was found to dose-dependently suppress the elevation of intracellular $\mathrm{Ca}^{2+}$ concentration and the phosphorylation of Syk kinase induced by the antigen stimulation. Furthermore, these effects were completely confirmed by the use of aglycon prepared from SO-1, indicating that SO-1 was the potent active constituent in the aqueous spinach extract.

Although SO-1 and its aglycon effectively suppressed the IgEmediated degranulation at the concentrations of $0.5 \sim 10 \mu \mathrm{g} / \mathrm{ml}$, both compounds had no inhibitory effect on calcium ionophore A23187induced degranulation at the same concentrations tested. These results indicate that the dose-dependent suppression of intracellular $\mathrm{Ca}^{2+}$ concentration by these compounds is due to the inactivation of the upstream component in signaling pathway such as Syk kinase, but not the inhibition of influx of extracellular $\mathrm{Ca}^{2+}$ ions. Thus, it is apparent that both SO-1 and its aglycon have the same mechanism to inhibit the antigen-stimulated activation of Syk kinase effectively and Lyn kinase weakly. Syk is one of the most important signaling molecules in IgE-mediated degranulation [20-22], and the degranulationinhibitory activities of many natural substances are demonstrated to be mediated through the inactivation of Syk. However, it is difficult to speculate that these compounds can directly regulate the intracellular tyrosine kinases, because SO-1 is considered to hardly transporte across the cell membrane due to its glycoside form. In addition, many literatures demonstrate that flavonoid compounds might be not physiologically incorporated into the cells. Therefore, it is acceptable to speculate that the flavonoid compounds such as SO-1, its aglycon, quercetin and luteolin may interact with the antigen-antibody-coupled 
Morishita Y (2015) Flavonoid glucuronides isolated from spinach inhibit IgE-mediated degranulation in basophilic leukemia RBL-2H3 cells and passive cutaneous anaphylaxis reaction in mice

FceRI complexes on the cell surface of RBL-2H3 cells. For examples, the disturbance of antigen binding to IgE, aggregate formation and conformational change of receptor complexes may occur on the cell surface in the presence of flavonoid compounds. In this study, it was apparently demonstrated that the phosphorylation of Syk kinase induced by antigen stimulation was effectively inhibited by both SO-1 and its aglycon. From these results, we may conclude that SO-1 and its aglycon suppress the degranulation in RBL-2H3 cells caused by the antigen stimulation through the inactivation of Syk kinase. However, further study is needed to clarify the exact action point of these flavonoids leading to the inactivation of Syk kinase.

Some glucuronides such as quercetin 3-O-glucuronide and apigenin 7-O-glucuronide are reported to have low inhibitory effects on IgE-mediated degranulation as compared with their aglycon forms [2]. However, flavonol glucuronide SO-1 isolated from spinach showed the similar inhibitory activity as its aglycon. These results indicate that the conjugation of sugars at $\mathrm{A}$ and $\mathrm{C}$ rings of flavonoids considerably reduce their potential activities, while the conjugation of sugars at $\mathrm{B}$ ring of flavonoids like $\mathrm{SO}-1$ showed no effect on the activity. Moreover, SO-2 and SO-3 were less active than SO-1 and its aglycon, indicating that the methylenedioxy linkage at $\mathrm{A}$ ring is essential for the enhancement of activity. A hydroxyl group at C5 position of A ring is also considered to be necessary for the activity, being in agreement with the findings for quercetin, kaempferol, baicalein and luteolin [14,17]. SO-1 specifically distributes in spinach, because this compound has not been isolated from other species of vegetables.

PCA reaction in mice is one of the most important in vivo models for the evaluation of antiallergic effects. Both SO-1 and its aglycon significantly reduced the PCA reaction at the oral dose indicated as well as the authentic drug, oxatomide. The aglycon exhibited the potent suppressive effect than SO-1, supporting that the aglycon is an active component of SO-1. It is observed that the aglycons of flavonoids are absorbed well through the small intestine membranes than their glycosides and the aglycons absorbed are metabolized in vivo to their conjugated forms, such as glucuronide, sulfates and mercapturates $[23,24]$. Consequently, the aglycon of SO-1 may be metabolized again to its glucuronide form after absorption, which still has a potent granulation-inhibitory activity around the target cells including mast cells and basophils.

This is the first report describing the antiallergic effect of flavonoid glucuronide (SO-1) isolated from spinach, demonstrating the usefulness of this compound for the improvement of allergic symptoms in humans. Further study is needed to investigate the availability of spinach as a functional vegetable to prevent and/or improve type I allergy.

\section{References}

1. Kawasaki M, Toyoda M, Teshima R, Sawada J, Hayashi T, et al. (1994) In vitro antiallergic activity of flavonoids in histamine Release assay using rat basophilic leukemia (RBL-2H3) cells. J Food Hyg Soc Japan 35: 497-503.

2. Yamamoto M M, Ema K, Shibuich I (2007) In vitro and in vivo anti-allergic effects of 'benifuuki' green tea containing O-methylated catechin and ginger extract enhancement. Cytotechnology 55: 135-142. [Crossref]

3. Itoh T, Ninomiya M, Yasuda M, Koshikawa K, Deyashiki Y, et al. (2009) Chalcone glycosides isolated from aerial parts of Brassica rapa L. 'hidabeni' suppress antigenstimulated degranulation in rat basophilic leukemia RBL-2H3 cells. Bioorg Med Chem 18: 7052-7057. [Crossref]

4. Stone KD, Prussin C, Metcalfe DD (2010) IgE, mast cells, basophils, and eosinophils. J Allergy Clin Immunol 125: S73-S80. [Crossref]

5. Bergman M, Varshavsly L, Gottlieb HE, Grossman G (2001) The antioxidant activity of aqueous spinach extract: chemical identification of active fractions. Phytochemistry 58: 143-152. [Crossref]

6. Edenharder R, Keller G, Platt KL, Unger KK (2001) Isolation and characterization of structurally novel antimutagenic flavonoids from spinach (Spinacia oleracea). J Agric Food Chem 49: 2767-2773. [Crossref]

7. Pandjaitan N, Howard LR, Morelock T, Gil MI (2005) Antioxidant capacity and phenolic content of spinach as affected by genetics and maturation. J Agric Food Chem 53: 8618-8623. [Crossref]

8. Bergquist SAM, Gertsson UE, Knuthsen P, Olsson ME (2005) Flavonoids in baby spinach (Spiacia oleracea L.): changes during plant growth and storage. J Agric Food Chem 53: 9459-9464. [Crossref]

9. Bergman M, Perelman A, Dubinsky Z, Grossman S (2003) Scavenging of reactive oxygen species by a novel glucurinated flavonoid antioxidant isolated and purified from spinach. Phytochemistry 62: 753-762. [Crossref]

10. Ferreres F, Castaner M, Tomas-Barberan FA (1997) Acylated flavonol glycosides from spinach leaves (Spinacia oleracea). Phytochemistry 45: 1701-1705.

11. Heo JC, Park CH, Lee HJ, Kim SO, Kim TH, Lee SH (2010) Amelioration of asthmatic inflammation by an aqueous extract of Spinacia oleracea Linn. Int J Mol Med 25: 409414. [Crossref]

12. Kawai M, Hirano T, Higa S, Arimitsu J, Maruta M, et al. (2007) Flavonoids and related compounds as anti-allergic substances. Allergol Int 56: 113-123. [Crossref]

13. Jeferson L, Franco TP, Fabiana M, Moacir GP, Adair RS dos Santos, et al. (2010) Structure-activity relationship of flavonoids derived from medicinal plants in preventing methylmercury-induced mitochondrial dysfunction. Environ Toxicol Pharmacol 30: 272-278. [Crossref]

14. Morimoto Y, Yasuhara T, Sugimoto A, Inoue A, Hide I, et al. (2003) Anti-allergic substances contained in the pollen of Cryptomeria japonica possess diverse effects on the degranulation of RBL-2H3 cells. J Pharmacol Sci 92: 291-295. [Crossref]

15. Fischer MJE, Paulussen JJC, Horbach DA, Roelofsen PW, van Miltenburg C de Mol $\mathrm{J}$, et al. (1995) Inhibition of mediator release in RBL-2H3 cells by some H1-antagonist derived anti-allergic drugs: Relation to lipophilicity and membrane effects. Inflamm Res 44: 92-97. [Crossref]

16. Xu F, Matsuda H, Hata H, Sugawara K, Nakamura S, et al. (2009) Structures of new flavonoids and benzofuran-type stilbene and degranulation inhibitors of rat basophilic leukemia cells from the Brazilian herbal medicine Cissus sicyoides. Chem Pharm Bull 57: 1089-1095. [Crossref]

17. Nakamura R, Watanabe K, Oka K, Ohta S, Mishima S, et al. (2010) Effects of propolis from different areas on mast cell degranulation and identification of the effective components in propolis. Int Immunopharmacol 10: 1107-1112. [Crossref]

18. Kondo K, Uchida R, Tokutake S, Maitani T (2006) Polymeric grape-seed procyanidins, but not monomeric catechins and oligomeric procyanidins, impair degranulation and membrane ruffling in RBL-2H3 cells. Bioorg Med Chem 14: 641-649. [Crossref]

19. Ishida M, Nishi K, Watanabe H, Sugahara $T$ (2013) Inhibitory effect of aqueous spinach extract on degranulation of RBL-2H3 cells. Food Chem 136, 322-327. [Crossref]

20. Costello PS, Turner M, Walters AE, Cunningham CN, Bauer PH, et al. (1996) Critical role for the tyrosine kinase Syk in signalling through the high affinity IgE receptor of mast cells. Oncogene 13, 2595-2605. [Crossref]

21. Zhang J, Berenstein EM, Evans RL, Siraganian RP (1996) Transfection of Syk protein tyrosine kinase reconstitutes high affinity IgE receptor-mediated degranulation in a Syk-negative variant of rat basophilic leukemia RBL-2H3 cells. J Exp Med 184: 71-79. [Crossref]

22. Ghosh D, Tsokos GC (2010) Spleen tyrosine kinase: an Src family of non-receptor kinase has multiple functions and represents a valuable therapeutic target in the treatment of autoimmune and inflammatory diseases. Autoimmunity 43: 48-55. [Crossref]

23. Heiss C, Keen CL, Kelm MF (2010) Flavanols and cardiovascular disease prevention. Eur Heart J 31: 2583-2592. [Crossref]

24. van Duynhoven J, Vaughan EE, Jacobs DM, Kemperman RA, van Velzen EJ, et al (2011) Metabolic fate of polyphenols in the human superorganism. Proc Natl Acad Sci USA 108: 4531-4538. [Crossref]

Copyright: (C)2015 Morishita Y. This is an open-access article distributed under the terms of the Creative Commons Attribution License, which permits unrestricted use, distribution, and reproduction in any medium, provided the original author and source are credited. 